\title{
Stereoselective high-performance liquid chromatographic assay for pirmenol enantiomers in dog plasma
}

\author{
NANCY JANICZEK*, HOWARD N. BOCKBRADER, TSUN CHANG, GORDON L. AMIDON and \\ DAVID E. SMITH \\ College of pharmacy. The University of Michigan. 428 Charch Sireet. Ann Albor. MI 48109 (USA)* and \\ Pharmacokinetics/Drug Mejabolism Department. Parke-Davis Pharmace'vical Rescurch Division, Warmer \\ Lambert Company. Amm Arbor. MI 40305 (USA)
}

(First received March 14th, 1991; revised manuscript received May 31s1, I991)

\begin{abstract}
Pirmenol enantiomers in dog plasma were quantified using a stereospecific high-performance liquid chromatographic method with iltraviolet detection at $262 \mathrm{~nm}$. Racemic pirmenol and internal standard. (+)-propranolol. were isolated trom dog plasma by a three-step extraction procedure using toltene, $0.1 M$ hydrochloric acid and hexane, iespectively. A chiral analytical column (Chiralcel O.l) vas used with a mobile phase consisting of hesan--isopropanol-diethylamine (98.9:1 0:0.1). Linear calibration curves swere obtained in the concentration range $0.0200-5.00 \mu \mathrm{g} / \mathrm{ml}$ for each enantiomer. Precision of the method, expressed as coefficient of variation for nine quality control samples, was $7.1 \%$ for $(+)$-pirmenol and $6.4 \%$ for $(-)$-pirmenol. Bias was $\pm 2.2 \%$ for $(+)$-pirmenol and $\pm 1.5 \%$ for $(-)$-pirmenol in quality control samples.
\end{abstract}

\section{INTRODUCTION}

Pirnenol, $\quad( \pm)-c i s-\alpha-[3-(2,6-$ dimethyl-1-piperidinyl)propyl]- $\alpha$-phenyl-2-pyridinemethanol monohydrochloride monohydrate, is a chiral compound (Fig. 1) being investigated as an antiarrhythmic agent. Pirmenol is administered as a racemic mixture and its pharmacokinetics have been studied in healthy subjects and patients with dysrhythmia [1-4]. Analytical methods used for these studies quantified pirmenol as a racemi: mixture without distinguishing between enantiomers $[5,6]$. Investigation of possible stereoselective differences in pharmacokinetics, metabolism and pharmacodynamics of pirmenol requires a mathod for quantitation of its enantiomers in biological samples.

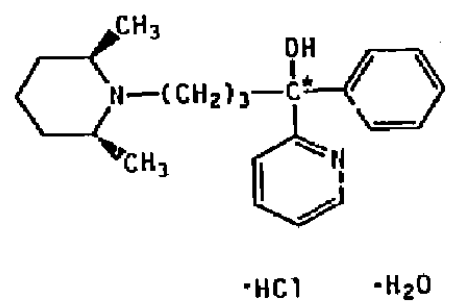

Fig. I. Structure of pirmenol (CI-845). The astirisk denotes the location of the chiral center. 
Since derivatization of pirmenol was not successful, several chiral columns were investigated for the separation of pirmenol enantiomers. A chiral HyproCu-Daltosil column (Serva, New York, NY, USA) was îrst tried since it was reported to separate pirmenol enantiomers in dog and human urine [7]. However, this column did not provide adequate separation at typical racemic pirmenol concentrations in plasma $(<1.0 \mu \mathrm{g} / \mathrm{ml})$ following therapeutic doses. An $\alpha_{1}$-acid glycoprotein column (LKB EnantioPac, Bromma, Sweden) also separated pirmenol enantiomers, but racemic concentrations less than $0.5 \mu \mathrm{g} / \mathrm{ml}$ could not be quantified accurately. For pharmacokinetic studies, a detection limit of at least $0.1 \mu \mathrm{g} / \mathrm{ml}$ racemic pirmenol would be required.

The method described uses cellulose tris(4-methylbenzoate) adsorbed on silica gel [8] as a chiral stationary phase (Chiralcel OJ, Daicel, Tokyo, Japan) for separation of pirmenol enantiomers. Linearity, precision and accuracy were evaluated following analysis of culibration standards and quality control samples prepared in dog plasma. Possible differences in the pharmacokinetics and pharmacodynamics of each enantiomer are currently being evaluated using this high-performance liquid chromatographic (HPLC) method for quantitation of $(+)$-pirmenol and $(-)$-pirmenol in plasma.

\section{EXPERIMENTAL}

\section{Chemicals}

Racemic pirmenol hydrochloride and pirmenol free base were synthesized, and pirmenol enantiomers were separated at the Parke-Davis Pharmaceutical Research Division. Warner Lambert (Ann Arbor, MI, USA). Internal standard used for the assay was (+)-propranolol hydrochloride (Sigma, St. Louis, MO, USA). Mobile phase consisted of HPLC-grade hexane (EM Science, Gibbstown, NJ, USA), HPLC-grade isopropanol (Baxter, Burdick and Jackson Division, Muskegon, MI, USA) and diethylamine (Sigma). Glassware was silanized using a $10 \%$ solution of dichlorodimethy!silane (Sigma) in HPLC-grade toluene (Baxter, Burdick and Jackson Division). Hydrochloric acid and sodium hydroxide solutions were prepared using standard volumetric solutions purchased from $\mathbf{J}$. T. Baker (Phillipsburg, NJ, USA) with HPLC-grade water (EM Science). Control beagle dog plasma was obtained at the Parke-Davis Pharmaceutical Research Division, Warner Lambert. Contral human plasma was purchased from Interstate Blood Bank (Memphis, TN, USA).

\section{Prepcitation of soluticins}

A $250 \mu \mathrm{g} / \mathrm{ml}$ stock solution of racemic pirmenol and a $100 \mu \mathrm{g} / \mathrm{ml}$ stock solution of (+)-propranolol were prepared in $0.01 M$ hydrochloric acid using silanized volumetric flasks. A $25 \mu \mathrm{g} / \mathrm{ml}$ racemic pirmenol stock solution was prepared by dilution (1:10) of the $250 \mu \mathrm{g} / \mathrm{ml}$ stock solution. Concentrations represent free base equivalents. Stock solutions were diluted with $0.01 M$ hydrochloric acid for 
preparation of calibration standards in silanized volumetric flasks. Concentrations of pirmenol enantiomers in calibration standard solutions ranged from 0.100 to $25.0 \mu \mathrm{g} / \mathrm{ml}$. Internal standard solution $(2.50 \mu \mathrm{g} / \mathrm{ml})$ was prepared by dilution (1:40) of internal standard stock solution with $0.01 \mathrm{M}$ hydrochloric acid.

Quality control samples containing racemic pirmenol were prepared at 0.0600 , 0.300 and $1.50 \mu \mathrm{g} / \mathrm{ml}$ of each enantionner. Appropriate volumes of 25 or 250 $\mu \mathrm{g} / \mathrm{ml}$ stock solutions were added to silarized $25-\mathrm{m}$ l volumetric fiasks and brought to volume with control beagle dog prasma. Aliquots of quality control samples were stored at $-15^{\circ} \mathrm{C}$ in silanized glass tubes.

\section{Extraction procedure}

For calibration standards, $0.5 \mathrm{ml}$ of control dog plasma and $0.1 \mathrm{ml}$ of calibration standard solution containing racemic pirmenol were combined in a 100 $\mathrm{mm} \times 16 \mathrm{~mm}$ disposable glass culture tube. A $0.5-\mathrm{ml}$ aliquot of dog plasma and $0.1 \mathrm{ml}$ of $0.01 M$ hydrochloric acid were used for quality controls and study samples. A $0.1-\mathrm{ml}$ aliquot of $2.5 \mu \mathrm{g} / \mathrm{ml}$ internal standard solution and $0.2 \mathrm{ml}$ of 1 $M$ sodium hydroxide were added to each tube. The mixture was extracted with 5 $\mathrm{ml}$ of toluene by shaking for $10 \mathrm{~min}$, centrifuged at $750 \mathrm{~g}$ for $5 \mathrm{~min}$, and the aqueous layer was frozen in a dry ice-acetone bath. The remaining toluene was transferred to a $15-\mathrm{ml}$ disposable glass centrifuge tube, back-extracted with $0.5 \mathrm{ml}$ of $0.1 M$ hydrochloric acid by shaking for $10 \mathrm{~min}$ and centrifuged at $420 \mathrm{~g}$ for 5 $\min$. $T h_{1} 2$ aqueous layer was frozen in a dry ice-acetone bath and to!uene was discarded. After thawing, $0.2 \mathrm{ml}$ of $1 \mathrm{M}$ sodium hydroxide was added and the mixture was extracted with hexane by shaking for $10 \mathrm{~min}$ followed by centrifugation at $420 \mathrm{~g}$ for $5 \mathrm{~min}$. The aqueous layer was frozen in a dry ice-acetone bath and hexane was transferred to a silanized $75 \mathrm{~mm} \times 12 \mathrm{~mm}$ disposable glass culture tube. Hexane was evaporated under nitrogen gas and the residue was dissolved in $200 \mu \mathrm{l}$ of mobile phase. A $175-\mu 1$ aliquot was injected into the HPLC system.

\section{Chromatography}

The HPLC system consisted of a Model 590 solvent delivery module, a Model 712 autosampler, Models CHM and TCM column temperature-controlling system (Waters, Milford, MA, USA), and a Model 8490 ultraviolet absorbance detector and Chromjet integrator (Spectra-Physics, San Jose, CA, USA).

Pirmenol enantiomers and internal standard were separated using a Chiralcel OJ column with $10 \mu \mathrm{m}$ particle size and dimensions of $25 \mathrm{~cm} \times 4.6 \mathrm{mrii}$ I.D. (J. T. Baker) and a mobile phase of hexane-isopropanol-diethylamine (98.9:1.0:0.1, $\mathrm{v} / \mathrm{v})$. Flow-rate was $1.0 \mathrm{ml} / \mathrm{min}$, column temperature was maintained at $65^{\circ} \mathrm{C}$, and absorbance was monitored at $262 \mathrm{~nm}$.

Calibration standards and quality control samples were analyzed in triplicate 
on three separate days for a total of nine determinations at each concentration. Calibration standard concentrations ranged from 0.0200 to $5.00 \mu \mathrm{g} / \mathrm{ml}$ for (+)pirmenol and (-)-pirmenol $(0.0400-10.0 \mu \mathrm{g} / \mathrm{ml}$ racemic pirmenol). Pirmenol enantiomer concentrations in quality control samples of dog plasma were 0.0600 , 0.300 and $1.50 \mu \mathrm{g} / \mathrm{ml}(0.120,0.600$ and $3.00 \mu \mathrm{g} / \mathrm{ml}$ racemic pirmenol). Leastsquares linear regression with a weighting factor of 1 /concentration was used to construct calibration curves for peak-height ratio as a function of pirmenol enantiomer concentration. Regression parameters (slope; $y$-intercept) were used to calculate (+)-pirmenol and (-)-pirmenol concentrations in calibration standards, quality control samples and $i n$ vivo plasma samples.

Recovery

Recovery of pirmenol enantiomers from dog plasma was determined at calibration standard concentrations of $0.0500,0.250$ and $2.50 \mu \mathrm{g} / \mathrm{ml}(+)$-pirmenol and (-)-pirmenol $(0.100,0.500$ and $5.00 \mu \mathrm{g} / \mathrm{ml}$ racemic pirmenol). Nine determinations wr:re performed at each concentration. Peak heights of $(+)$-pirmenol, (-)-pirminol and internal standard following extraction from dog plasma were compared with mean peak heights from nine injections of reference (non-extracted) standards. For reference standards, stock solutions of racemic pirmenol free base in isopropanol and (+)-propranolol hydrochloride (internal standard) in methanol were prepared. Aliquots of these stock solutions were pipetted into silanized volumetric flasks, solvents were evaporated under nitrogen, and residue was dissolved in hexane-isopropano!-diethylamine $(99.1: 0.8: 0.1, \mathrm{v} / \mathrm{v})$.

\section{Dog plasma samples}

A single $5 \mathrm{mg} / \mathrm{kg}$ intravenous dose of racemic pirmenol was administered to two male beagle dogs. The dose was prepared in $0.9 \%$ saline and given as a 5 -min infusion. Serial blood samples were obtained for $8 \mathrm{~h}$ following the end of the infusion. After centrifugation, plasma was separated and stored frozen at $-15^{\circ} \mathrm{C}$ until assayed. Pirmenol enantiomer concentrations in dog plasma were determined using the method described. Pharmacokinetic parameters were calculated using non-compartmental methods [9].

\section{RESULTS AND DISTUSSION}

\section{Chromatography,}

Representative chromatograms of pirmenol enantiomers in dog plasma are shown in Fig. 2, where retention times of $(+)$-pirmenol, $(-)$-pirmenol and internal standard are $7.4,9.2$ and $20.9 \mathrm{~min}$, respectively. No chromatographic peaks at retention times of pirmenol enantiomers or internal standard were observed in control dog plasma. In addition, control human plasma did not show any interfering peaks, suggesting that this method may also be applicable to human plasma samples. 

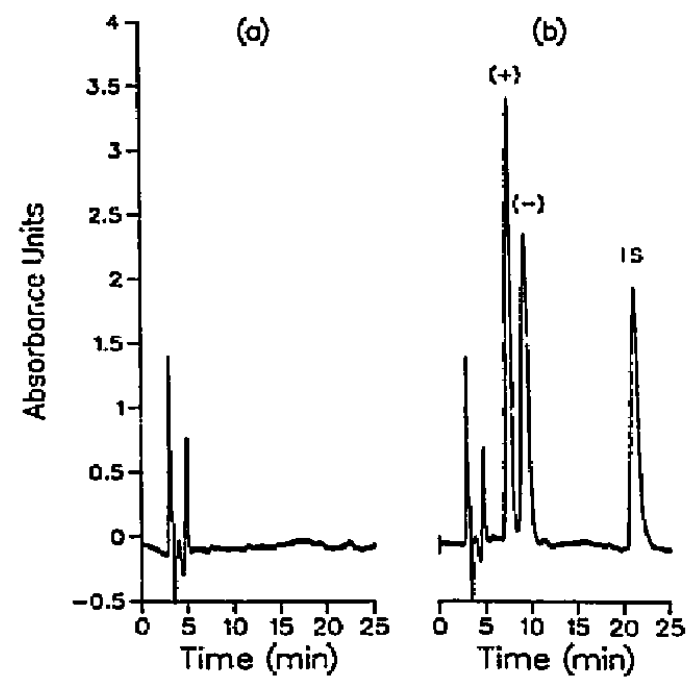

(c)

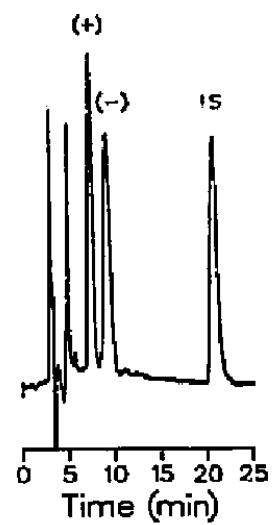

Fig. 2. Chromatograms of (a) control dog plasma with no pirmenol or internal standard added, (b) a calibration standard containing $0.500 \mu \mathrm{g} / \mathrm{ml}(+)$-pirmenol and (-)-pirmenol $(1.00 \mu \mathrm{g} / \mathrm{ml} \mathrm{racemic}$ pirmenol) and internal standard, and (c) a dog plasma sample obtained $45 \mathrm{~min}$ after the end of a 5 -min infusion of $5 \mathrm{mg} / \mathrm{kg}$ racemic pirmenol. Peaks: $(+)=(+)$-pirmenol; $(-)=(-)$-pirmenol; IS $=$ internal standard. (+)-propranolol.

Elution order of enantiomers was identified by comparing retention times of $(+)$-pirmenol and $(-)$-pirmenol reference standards to retention from racemic pirmenol.

\section{Calibration standards}

Calibration curves were linear over the concentration range $0.0200-5.00 \mu \mathrm{g} / \mathrm{ml}$ for $(+)$-pirmenol and $(-)$-pirmenol in dog plasma. Regression parameters (slope; $y$-intercept; coefficient of determination, $r^{2}$ ) calculated following analysis of nine sets of calibration standards are shown in Table I. Variability of slope, as judged by coefficient of variation, was less than $3.0 \%$ for both enantiomers.

Mean calculated concentrations of calibration standards analyzed in triplicate on three separate days are shown in Table II. The coefficient of variation (C.V.) for nine determinations was $5.9 \%$ or less for $(+)$-pirmenol and $7.9 \%$ or less for $(-)$-pirmenol. The bias, calculated as the percentage difference from theoretical concentration, was $\pm 3.5 \%$ for $(+)$-pirmenol and $\pm 5.5 \%$ for $(-)$-pirmenol.

\section{Quality conirols}

Table III contains mean calculated concentrations for quality control samples containing racemic pirmenol in dog plasma. Precision was at least $7.1 \%$ for each enantiomer in quality control samples; based on C.V. values for $(+)$-pirmenol and $(-)$-pirmenol. Calculated concentrations were within $2.2 \%$ of actual concentrations for both pirmenol enantiomers. Precision and accuracy were also evaluated for the three determinations performed on each day (intra-day) and for 


\section{TABLE I}

INDIVIDUAL AND MEAN $(n=\eta)$ REGIKESSION PARAMETERS FOR PIRMENOL ENANTIOMERS IN DOG PLASMA FOLLOWING ASSAY OF CALIBRATION STANDARDS IN TRIPLICATE ON THIREE SEPARATE DAYS

Calibration concentratious ranged from 0.0200 to $5.00 \mu \mathrm{g} / \mathrm{ml}(+)$-pirmenol and $(-)$-pirmenol; $r^{2}=$ coeflicient of determination.

\begin{tabular}{|c|c|c|c|c|c|c|c|}
\hline \multirow[t]{2}{*}{ Dily } & \multirow{2}{*}{$\begin{array}{l}\text { Curve } \\
\text { No. }\end{array}$} & \multicolumn{3}{|c|}{$(+)$-Pirmenol } & \multicolumn{3}{|c|}{ (-)-Pirmenol } \\
\hline & & Slope & !-Intercept & $r^{2}$ & Slope & v-Intercept & $r^{2}$ \\
\hline \multirow[t]{3}{*}{1} & 1 & 3.16 & 0.0174 & 0.9985 & 2.21 & 0.0051 & 0.9978 \\
\hline & 2 & 3.21 & 0.0169 & 0.9998 & 2.24 & 0.0017 & 0.9997 \\
\hline & 3 & 3.28 & 0.0141 & 0.9995 & 2.30 & 0.0028 & 0.9990 \\
\hline \multirow[t]{3}{*}{2} & 4 & 3.29 & 0.0294 & 0.9987 & 2.27 & 0.0127 & 0.9989 \\
\hline & $5^{a}$ & 3.30 & 0.0343 & 0.9994 & 2.27 & 0.0096 & 0.9991 \\
\hline & 6 & 3.16 & 0.0268 & 0.9997 & 2.20 & 0.0094 & 0.9997 \\
\hline \multirow[t]{3}{*}{3} & 7 & 3.26 & 0.0063 & 0.9998 & 2.26 & -0.0034 & 0.9998 \\
\hline & 8 & 3.33 & 0.0041 & 0.9995 & 2.30 & -0.0020 & 0.9996 \\
\hline & 9 & 3.46 & 0.0078 & 0.9997 & 2.39 & -0.0030 & 0.9996 \\
\hline Mean & & 3.27 & 0.0175 & 0.9994 & 2.27 & 0.0037 & 0.9992 \\
\hline S.D. & & 0.09 & 0.0107 & 0.0005 & 0.06 & 0.0059 & 0.0006 \\
\hline
\end{tabular}

"Calibration standard concentrations ranged from 0.0250 to $5.00 \mu \mathrm{g} / \mathrm{ml}$ pirmenol chantiomers.

TABLE 11

MEAN $(n=9)$ CALCULATED CONCENTRATIONS OF ( +)-PIRMENOL AND (-)-PIRMENOL IN CALIBRATION STANDARDS ANALYZED IN TRIPLICATE ON THREE SEPARATE DAYS

\begin{tabular}{|c|c|c|c|c|c|c|}
\hline \multirow{2}{*}{$\begin{array}{l}\text { Concen- } \\
\text { tration } \\
\text { added } \\
(\mu \mathrm{g} / \mathrm{ml})\end{array}$} & \multicolumn{3}{|l|}{$(+)$-Pismenol } & \multicolumn{3}{|l|}{ (-)-Pirmenol } \\
\hline & $\begin{array}{l}\text { Mean concentration } \\
\text { found }(\mu \mathrm{g} / \mathrm{ml})\end{array}$ & $\begin{array}{l}\text { C.V. } \\
(\%)\end{array}$ & $\begin{array}{l}\text { Bias } \\
(\%)\end{array}$ & $\begin{array}{l}\text { Moan concen!ration } \\
\text { found }(\mu \mathrm{g} / \mathrm{ml})\end{array}$ & $\begin{array}{l}\text { C.V. } \\
(\%)\end{array}$ & $\begin{array}{l}\text { Bias } \\
(\%)\end{array}$ \\
\hline 0.0200 & $0.0193^{\prime \prime}$ & 5.85 & -3.50 & 0.0189 & 5.77 & -5.50 \\
\hline 0.0250 & 0.0243 & 5.43 & -2.80 & 0.0238 & 7.94 & -4.80 \\
\hline 0.0500 & 0.0509 & 4.99 & 1.80 & 0.0512 & $7.2 \mathrm{I}$ & 2.40 \\
\hline 0.100 & 0.102 & 3.02 & 2.00 & 0.105 & 3.64 & 5.00 \\
\hline 0.250 & 0.253 & 2.75 & 1.20 & 0.255 & 3.84 & 2.00 \\
\hline 0.500 & 0.508 & 2.13 & 1.60 & 0.509 & 2.24 & 1.80 \\
\hline 1.00 & 1,01 & 3.33 & 1.00 & 1.01 & 3.61 & 1.00 \\
\hline 2.50 & 2.48 & 2.94 & -0.80 & 2.48 & 3.30 & -0.80 \\
\hline 5.00 & 5.01 & 1.53 & 0.20 & 5.00 & 1.51 & 0.00 \\
\hline
\end{tabular}

$n=8$. 
TABLE III

MEAN $(n=9)$ CALCULATED CONCENTRATIONS OF ( +)-PIRMENOL AND (-)-PIRMENOL IN QUALITY CONTROL SAMPLES ANALYZED IN TRIPLICATE ON THREE SEPARATE DAYS

\begin{tabular}{|c|c|c|c|c|c|c|}
\hline \multirow{2}{*}{$\begin{array}{l}\text { Concen- } \\
\text { tration } \\
\text { added } \\
(\mu \mathrm{g} / \mathrm{ml})\end{array}$} & \multicolumn{3}{|l|}{$(+)$-Pirmenol } & \multicolumn{3}{|l|}{ (-)-Pirmenol } \\
\hline & $\begin{array}{l}\text { Meiln concentration } \\
\text { found }(\mu \mathrm{g} / \mathrm{ml})\end{array}$ & $\begin{array}{l}\text { C.V. } \\
(\%)\end{array}$ & $\begin{array}{l}\text { Bias } \\
(\%)\end{array}$ & $\begin{array}{l}\text { Mean concentration } \\
\text { found }(\mu \mathrm{g} / \mathrm{ml})\end{array}$ & $\begin{array}{l}\text { C.V. } \\
(\%)\end{array}$ & $\begin{array}{l}\text { Biuts } \\
(\%)\end{array}$ \\
\hline 0.0600 & 0.0587 & 7.12 & -2.17 & 0.0609 & 6.44 & 1.50 \\
\hline 0.300 & 0.297 & 3.47 & -1.00 & 0.300 & 2.18 & 0.00 \\
\hline 1.50 & 1.53 & 4.33 & 2.00 & 1.52 & 4.22 & 1.33 \\
\hline
\end{tabular}

calibration standards analyzed on each of three days (inter-day). Intra-day assay precision (C.V.) ranged from 1.0 to $8.5 \%$ for (+)-pirmenol and from 0.7 to $8.9 \%$ for ( - )-pirmenol. Intra-day assay accuracy (bias) was $\pm 9.3 \%$ for $(+)$-pirmenol and $\pm 4.7 \%$ for $(-)$-pirmenol. Inter-day assay precision (C.V.) ranged from 2.5 to $10.5 \%$ and inter-day assay accuracy (bias) was within $4.2 \%$ for $(t)$-pirmenol. Inter-day precision (C.V.) ranged from 1.5 to $9.5 \%$ and inter-day accuracy (bias) was within $4.7 \%$ for $(-)$-pirmenol.

\section{Recovery}

Recovery of pirmenol enantiomers and internal standard from dog plasma is shown in Tatie IV. Mean $(n=9)$ recovery was approximately $80 \%$ for both pirmenol enantiomers over the concentration range $0.0500-2.50 \mu \mathrm{g} / \mathrm{ml}$, with C.V.

\section{TABLE IV}

RECOVERY OF PIRMENOL ENANTIOMERS AND INTERNAL STANDARD FROM DOG PLASMA

Recovery is expressed as ratio of peak height for (+)-pirmenol, (-)-pirmenol or internal standard after extraction from dog plasma to mean peak height after nine injections of non-extracted standards.

\begin{tabular}{lllll}
\hline Compound & $n$ & $\begin{array}{l}\text { Concentration } \\
(\mu \mathrm{g} / \mathrm{ml})\end{array}$ & $\begin{array}{l}\text { Man recovery } \\
(\%)\end{array}$ & $\begin{array}{l}\text { C.V. } \\
(\%)\end{array}$ \\
\hline (+)-Pirmenol & 9 & 0.0500 & 79.6 & 7.21 \\
& & 0.250 & 79.8 & 3.22 \\
(-)-Pirmenol & & 2.50 & 77.9 & 3.81 \\
& 9 & 0.0500 & 83.5 & 6.83 \\
Internal standard & & 0.250 & 79.6 & 3.38 \\
& 27 & 2.50 & 77.4 & 3.94 \\
\hline
\end{tabular}


TABLE $V$

STABILITY OF PIRMENOL ENANTIOMERS IN DOG PLASMA

Values are expressed as pereent of added $(+)$-pirmenol or (-)-pirmenol concentration in dog plasma quality control samples stored at $-15^{\circ} \mathrm{C}$ until analysis.

Concen- Percentage remuining

tration

added

$(\mu \mathrm{g} / \mathrm{ml})$

(+)-Pirmeno

(-)-Pirmenol

Two months Three months Four months

Two months Three months Four months

\begin{tabular}{lllcccc}
\hline 0.0600 & 93.3 & 93.0 & 96.7 & 103 & 94.0 & 97.3 \\
0.300 & 96.7 & 106 & 100 & 115 & 107 & 99.3 \\
1.50 & 96.7 & 101 & 96.0 & 96.7 & 102 & 96.7
\end{tabular}

values of $7.2 \%$ or less. Pirmenol enantiomers showed a slight decrease in recovery with increasing concentration. Mean $(n=27)$ internal standard recovery was $74 \%$.

\section{Stability}

Stability data for pirmenol enantiomers in quality control samples are listed in Table V. These values represent single determinations of pirmenol enantiomer concentrations in quality controls which were analyzed with study samples. Pirmenol enantiomers showed no degradation and are considered stable in dog plasma stored at $-15^{\circ} \mathrm{C}$ for at least four months.

Pirmenol enantiomer pharmacokinetics in beagle dogs

Following intravenous administration of racemic pirmenol $(5 \mathrm{mg} / \mathrm{kg})$ to two beagle dogs, plasma ( - -pirmenol concentrations were higher than $(+)$-pirmenol

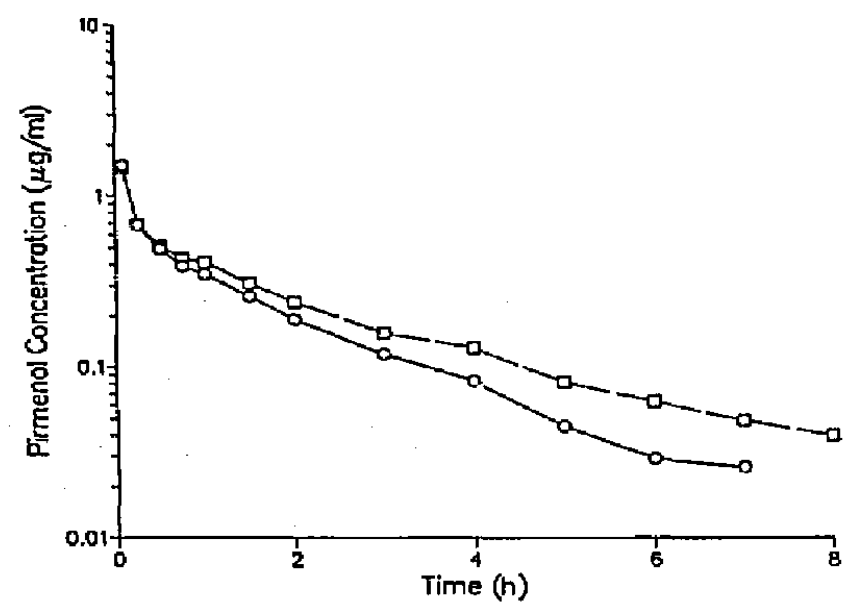

Fig. 3. Plasma concentration-time profile for $(\div)$-pirmenol $(O)$ and $(-)$-pirmenol $(\square)$ following a 5-min intravenous infusion of $5 \mathrm{mg} / \mathrm{kg}$ racemic pirmenol to a beagle $\mathrm{dog}$. 
concentrations. Fig. 3 shows a plasma concentration-time profile of pirmenol enantiomers in a representative dog. In this animal, terminal-phase half-life was 1.7 and $2.3 \mathrm{~h}$ for $(+)$-pirmeno! and $(-)$-pirmenol, respectively. Plasma clearance was $33.3 \mathrm{ml} / \mathrm{min} / \mathrm{kg}$ for $(+)$-pirmenol and $25.6 \mathrm{ml} / \mathrm{min} / \mathrm{kg}$ for $(-)$-pirmenol.

\section{CONCLUSION}

A normal-phase HPLC assay for pirmenol enantiomers has been developed and validated in dog plasma. Direct separation is achieved on a chiral stationary phase (Chiralcel OJ) without derivatization. Calibration curves are linear in the concentration range $0.0200-5.00 \mu \mathrm{g} / \mathrm{ml}$ for $(+)$-pirmenol and (-)-pirmenol. This method can be used for the pharmacokinetic evaliation of pirmenol enantiomers in dogs following administration of racemic pirmenol.

\section{ACKNOWLEDGEMENTS}

The authors gratefully acknowiedge the advice of $\mathrm{Mr}$. Dino Sherwood, $\mathrm{Mr}$. Timothy Hurley and Dr. Vladimir Beylin (Parke-Davis Pharmaceutical Research Division, Warner Lambert) in the development of the separation method for pirmenol enantiomers. The authors also wish to thank Mr. Robert Bonczyk, Mr. James Burleigh and Ms. Debbie Gillies (Parke-Davis Pharmaceutical Research Division, Warner Lambert) for conducting the animal studies.

\section{REFERENCES}

I K. A. Stringer, A. B. Cetnarowski, A. Goldfarb, M. E. Lebsack, T. Chang and A. J. Sedman, J. Clin. Pharmacol., 28 (1988) 1094-1097.

2 S. C. Hammill, D. G. Sland, P. A. Routledge, M. C. Hindman, J. T. Baker and E. L. C. Pritchett, Circulation, 65 (1982) 369-375.

3 T. G. Lee, A. D. Goldberg, T. Chang, M. T. Serkland, G. J. Yakatan, E. L. Johnson, J. G. Toole and S. Goldstein, J. Cardiorasc. Pharmacol., 5 (1983) 632-637.

4 S. W. Sanders, J. M. Nappi, R. L. Foltz, J. R. Lutz and J. L. A.nderson, J. Clin. Phamacol.. 23 (1983) 113-122.

5 D. G. Shand, C. Varghese, A. Barchowsky, S. C. Hammill and E. L. C. Pritchett, $J$. Chromarogr., 224 (1981) 343-352.

6 E. L. Johnson and L. A. Pachla, J. Plarm. Sci., 73 (1984) 754-756.

7 W. Klemisch and A. von Hodenberg, J. High Resolut. Chromatogr.. 13 (1990) 525-526.

8 Y. Okamoto, R. Aburatani and K. Hatada, J. Chromanogr., 389 (1987) 95-i02.

9 M. Gibaldi and D. Perrier, Phamacokinetics, Marcel Dekker, New York, 2nd ed., 1982, pp. $409-417$. 